3. Dan`shy`na N. V. (2013). Specificity of performance of the Renaissance vocal music in the conditions of national choral practice. Candidate`s thesis. [in Ukrainian].

4. Dem yanenko B. (2018). Treatise " Preporciya " from the Kiev manuscript of the XVIII century: critical publication of the text Vy`davecz' Taras Tetyuk. L`viv. [in Ukrainian].

5. Diletskiy Nikolay. (1979). Musikijskaya's grammar idea [publication, translation, research and commentary by Protopopov]. M. Muzyka. [in Russian].

6. Ignatenko Ye.V. (2005). "High style" choral concert of the late XVII-XVIII centuries: to the problem of musical and poetic integrity. Ky`yiv. Candidate`s thesis. [in Ukrainian].

7. Kuz`mins`kij I. (2014.) Origins, musical theory and performing practice of partisan polyphony. Candidate`s thesis. Ky`yiv. [in Ukrainian].

8. Kuzems`ka Ganna. (2012). What language did ancient Ukraine pray: the rules of Ukrainian transliteration of Church Slavonic texts K. KZhD «Sofiya». [in Ukrainian].

9. Pry xod'ko O. (2017). Choral music A Cappella of the second half of the XX - beginning of the XXI century ... theoretical comprehension and performance approaches Ky`yiv. [in Ukrainian].

Стаття надійшла до редакиії 07.02.2019 p.

УДК 78.03+784.3“17”

\author{
Омельченко-Агай Кухі Галина Сергї̈вна, \\ здобувач кафедри старовинної музики \\ Національної музичної академії України \\ імені П. І. Чайковського \\ ORCID 0000-0002-5561-9594 \\ galina-aghaie@yandex.ua
}

\title{
ПЕРЕТВОРЕННЯ ЖАНРОВОГО ІНВАРІАНТУ СОЛЬНОЇ КАНТАТИ У ТВОРЧОСТІ В. А. МОЦАРТА
}

Мета статті полягає у спробі вперше звернути увагу на жанр сольної кантати, як на самостійний та вагомий з-поміж групи кантатних жанрів, осмислити функціонування жанру у композиторів класичного стилю та зафіксувати зміни параметрів його жанрового інваріанту. Методологія дослідження полягає у використанні аналітичного, компаративного та історичного методів. Дані методологічні підходи дозволяють порівняти та розкрити особливості перетворення жанрового інваріанту сольної кантати за доби бароко та класичного стилю, на прикладі творчості віденських класиків загалом та на творах В. А. Моцарта зокрема. Наукова новизна полягає у виявленні притаманних сольній кантаті жанрових параметрів доби класичного стилю та їх порівнянні iз параметрами кантати доби бароко. Висновки. Сольна кантата доби класичного стилю відрізняється від творів даного жанру попередньої історичної епохи. Завдяки їх порівнянню розкриваються особливі параметрир кожного із них, що дає змогу зафіксувати процес перетворення жанрового інваріанту сольної кантати.

Ключові слова: жанр, жанровий інваріант, сольна кантата, доба класичного стилю, кантати В. А. Моцарта.

Омельченко-Агай Кухи Галина Сергеевна, соискатель кафедры старинной музыки Национальной музыкальной академии Украины имени П. И. Чайковского

Преобразование жанрового инварианта сольной кантаты в творчестве В. А. Моцарта

Цель статьи заключается в попытке впервые обратить внимание на жанр сольной кантаты, как на самостоятельный и весомый среди группы кантатных жанров, осмыслить его функционирование у композиторов классического стиля и зафиксировать изменения параметров его жанрового инварианта. Методология исследования заключается в использовании аналитического, сравнительного и исторического методов. Данные методологические подходы позволяют сравнить и раскрыть особенности преобразования жанрового инварианта сольной кантаты в эпоху барокко и классического стиля на примере творчества венских классиков в целом и на произведениях В. А. Моцарта в частности. Научная новизна заключается в выявлении характерных для сольной кантаты жанровых параметров классического стиля и их сравнении с параметрами кантаты эпохи барокко. Выводы. Сольная кантата классического стиля отличается от произведений данного жанра предыдущей исторической эпохи. Благодаря их сравнению раскрываются особые параметры каждого из них, что позволяет зафиксировать процесс преобразования жанрового инварианта сольной кантаты.

Ключевые слова: жанр, жанровый инвариант, сольная кантата, эпоха классического стиля, кантаты В. А. Моцарта.

(C) Омельченко-Агай К. Г., 2019 
Omelchenko-Aghaie Koohi Galyna, postgraduate student of Early Music Department of Tchaikovsky National Music Academy of Ukraine

The transformation of the solo cantata's genre invariant in the works of $V$. A. Mozart

The purpose of the article is to try for the first time to pay attention to the genre of the solo cantata, as an independent and significant among the group of cantata genres, to comprehend its functioning among composers of the classical style and record the changes in the parameters of its genre invariant. The research methodology is to use analytical, comparative and historical methods. These methodological approaches allow us to compare and disclose the peculiarities of the transformation of the genre invariant of the solo cantata in the Baroque and classical style using the example of the work of Viennese classics in general and in the works of V. A. Mozart in particular. The scientific novelty consists in identifying the genre parameters of the classical style characteristic of the solo cantata and comparing them with the parameters of the Baroque cantata. Conclusion. The solo cantata of the classical style differs from the works of this genre of the previous historical era. Thanks to their comparison, the specific parameters of each of them are revealed, which allows one to fix the process of transformation of the genre invariant of the solo cantata.

Key words: genre, genre invariant, solo cantata, the era of the classical style, cantatas of W. A. Mozart.

Актуальність теми дослідження полягає у спробі вперше звернути увагу на жанр сольної кантати, як на самостійний та вагомий з-поміж групи кантатних жанрів. Історія його розвитку налічує понад чотириста років. Зародження та становлення жанру відбуваються за доби бароко на території Італії та виявляються через низку парамерів інваріанту, що якісно відокремлюють сольну кантату від інших жанрів. За доби бароко сольна кантата є одним із провідних жанрів - виразників епохи. Однак, починаючи із кінця XVIII ст., вона зміщується із центральної позиції на периферію жанрового фонду, продовжуючи свій розвиток завдяки особливій гнучкості щодо нових музично-естетичних стилів та напрямків. Саме тому, актуальним також $є$ осмислення функціонування жанру у композиторів класичного стилю на прикладі творчого доробку В. А. Моцарта. Необхідно підкреслити, що робота в жанрі сольної кантати цього майстра до сих пір не ставала в центрі музикознавчих досліджень. Важливим внеском даної статті також є спроба виявити особливості перетворення жанрового інваріанту сольної кантати та зміни ії параметрів відповідно до нових естетико-стилістичних умов.

Отже, метою розвідки $\epsilon$ фіксування зміни параметрів та виявлення особливостей перетворення жанрового інваріанту сольної кантати за доби класичного стилю на прикладі творчості В. А. Моцарта.

Аналіз досліджень і публікацій. Одразу варто зазначити, що сольна кантата досі не стала предметом грунтовних музикознавчих досліджень. Значна кількість вітчизняних праць, присвячених кантатним жанрам, загалом не сприяє виокремленню сольної кантати 3-поміж таких жанрів як: хорова кантата, велика вокально-хорова кантата, камерна кантата та ін. Тому основною теоретичною базою у даній розвідці стали матеріали довідникової літератури [14], теоретичні праці присвячені розвитку духовної сольної кантати за доби бароко [13], а також два каталоги сольних кантат у творчості єврейських композиторів та композиторів XVIII ст. [9; 12]. Музикознавчі праці присвячені класичному стилю та історичному періоду 20 -х років XVIII 20 -х років XIX століть [3; 7]. Окрему частину базових джерел складають роботи присвячені життю та творчості Й. Гайдна, В. А. Моцарта та Л. ван Бетховена $[1 ; 2 ; 4 ; 6 ; 10 ; 11]$.

Методи дослідження. Для досягнення поставленої мети були використані аналітичний, компаративний та історичний методи дослідження. Зокрема, проаналізовані сольні кантати віденських класиків. Порівняння творів барокової і класичної епох дало можливість виявити особливості перетворення жанрового інваріанту у другій половині XVIII ст. У процесі вивчення низки параметрів жанрового інваріанту, спираємось на дослідження «Функціонування інструментальних жанрових моделей західноєвропейського бароко в українській музиці другої половини XX ст.» I. Тукової [5]. Дослідниця пропонує наступну схему жанрового аналізу творів, що включає два основних рівні:

«Функціональний рівень:

- життєва функція (або соціально-культурна) - умови побутування конкретного жанру;

- склад виконавців.

Семантично-композиційний рівень:

жанровий зміст;

- $\quad$ композиційна схема;

- засоби жанрової виразності (найбільш характерні для даного конкретного жанру)» $[5,6]$.

Виклад основного матеріалу. Спробуємо провести жанр сольної кантати доби класичного стилю крізь рівні аналізу жанрового інваріанту та виявити характерні саме для нього параметри. 
Функціональний рівень. Соціально-культурна функція. На відміну від функціонування у якості барокового жанру-репрезентанта, сольна кантата у XVIII ст. зміщується із центральних позицій на периферію. Це відбувається насамперед через центральне положення опери в системі музичних жанрів XVIII - початку XIX ст. Завдяки інтенсивному розвитку оперної індустрії, яка виражається як через будівництво численних оперних театрів, створення театральних труп та оркестрів, що, в свою чергу, визиває попит на регулярне поповнення їх репертуару. Саме опера, як жанр, могла вмістити та втілити основні естетичні вподобання композиторів та публіки епохи класичного стилю - прагнення до досконалості та універсалізму, переконаність у можливості набуття ідеалу «тут і тепер» $[3,24]$, а також вираження у музичному творі загальнозначущих, важливих для всіх і кожного ідей $[3,27]$. Публіка сприймає кожну оперну виставу як соціальну подію, де виражені найсучасніші та етично-правильні події (що є вартими до загального споглядання), схеми поведінки героїв та їх характери. Сольна кантата за своїми розмірами та складом виконавців не може вмістити в собі висловлювання узагальнюючого типу, тому стає репертуарним твором аматорських зібрань, соціально-культурних спілок, написаних для спеціальної урочистої чи пам'ятної події (оказіональні) із можливою присвятою конкретній особі. Це впливає також на кількість сольних кантат написаних в період 31730 по 1820 років. Зокрема серед доробку віденських класиків, Й. Гайдна, В. Моцарта та Л. ван Бетховена сольних кантат близько 11. Серед численних творів В. Моцарта знаходимо п'ять сольних кантат, що написані на німецький текст, переважно духовно-релігійного змісту.

Одна із ранніх кантат «Погребальна музика» («Grabmusik», KV 42) написана в 1767 p. Виконання їі було приурочене до великого посту. Текст твору представляє духовний діалог, розмову між Душею (B) та Янголом (S). Кантата стає показовою у засвоєнні юним Моцартом так званого неаполітанського стилю (проникнення в церковні жанри форм та прийомів опери, особливо в мелодиці: фанфарна мелодика 3 широкими інтервалами, колоратури, виразність оркестру). Пізніше, в середині 70-х років, Моцарт додав до тексту кантати заключний хор 3 невеликим увідним речитативом. Отже маємо наступну послідовність номерів у кантаті: Речитатив Душі (B), Арія Душі (B, D-dur), Речитатив Янгола (S), Арія Янгола (S, g-moll), речитатив Душі, Дует Янгола та Душі (Esdur), речитатив Янгола, Хор (мішаний, C-dur) [1, I. 1., 140, 476, 485].

Кантата «До Тебе, душе всесвіту» (KV 429), створена приблизно в 1783 р., залишилась незавершеною. Аберт вказує на існування трьох редакцій кантати: для двох тенорів і басу у супроводі клавіру, для вокального тріо із фортепіано та для чотириголосного хору з супроводом струнного квартету, двох гобоїв, двох валторн і двох фаготів. [1, II. 1, 77]. Однак в коментарях К. Сакви вказано, що редакції для вокального тріо та хору, були зроблені значно пізніше, вже після смерті Моцарта його учнем М. Штадлером [1, II. 1, 448, 451, 452].

У 1785 р. була написана масонська кантата (KV 471) «Радість масона» для соло тенора, хору, у супроводі струнного квартету, двох гобоїв, двох валторн і кларнета, яка була виконана у Відні. Автором тексту став масон - брат Франц Петран.

Кантата (KV 619) «Ви, пошановувачі Творця безмежного всесвіту», липень 1791 р., на текст поета Франца Генріха Цигенхагена (17531806).

Остання кантата «Невелика масонська кантата» (KV 623), для двох тенорів та басу, текст Емануеля Шиканедера (17481812), написана в листопаді 1791 р. до освячення нового масонського храму. Кантата складається із шести частин: початковий та заключний хори (озвучують аналогічний матеріал), двох речитативів, арії тенора та дуету для тенора та баса. До того ж кантата має додаток, у вигляді ще одного хору, який в наш час $є$ австрійським національним гімном. Однак Аберт заперечує написання цього хору Моцартом [10, 248].

Тенденція до зменшення кількості сольних кантат проглядається і у композиторів раннього класичного стилю, і у митців так званого «другого ряду». Таким чином, у період з 1730 по 1820 роки сольна кантата стає репрезентантом та учасником процесу формування нового жанру - камерної музики, у прямому розумінні слова «камерна», тобто розрахованої на невелику кількість виконавців та обмежене коло слухачів. Окрім, як вже вказувалось, репертуарного твору аматорських зібрань, соціально-культурних спілок, написаних для спеціальної урочистої чи пам'ятної події (оказіональні) із можливою присвятою конкретній особі, сольна кантата є обов'язковим педагогічним репертуаром для співаків-вокалістів та композиторів у підготовці до виконання та створення жанру опери.

Склад виконавців. Поряд із творами, що нагадують за складом барокові зразки, з’являються й інші комбінації виконавців. Зокрема, клавір може бути замінений на фортепіано, інструментальний ансамбль - збільшений до струнного квартету із додаванням духових інструментів, або ж навіть оркестру. Окрім того, до деяких із сольних кантат композитори віденці додають хор. Чому ж варто зараховувати такі кантати до сольних? На це питання можливо відповісти після детального аналізу 
низки творів, оцінивши роль хору в композиції та загальній драматургії. Наприклад, у кантаті «Вибори капельмейстера» Й. Гайдна задіяний хор, однак він використовується лише двічі (наприкінці, № 8 та № 10), його роль коментуючого типу. Більшість номерів кантати відведена все ж таки для трьох солістів Аполлона (T), Бахуса (T) та Мінерви (S). Кожен із персонажів має сольні арії та речитативи. Між двома заключними хорами звучить дует Мінерви та Аполлона. Тому кількість

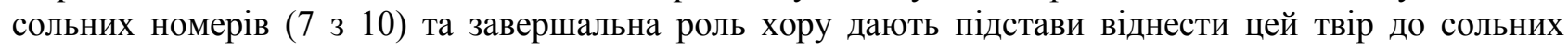
кантат, а не до хорових творів.

Частіше за все хорова партія має функцію вступу або заключення, особливо у творах, що несуть соціальне навантаження, присвячені до визначної дати та будуть виконані у досить широкому колі слухачів культурно-просвітницького зібрання. Наприклад, масонська кантата (KV 471) В. Моцарта «Радість масона» для соло тенора, хору, у супроводі струнного квартету, двох гобоїв, двох валторн і кларнета, виконана на честь австрійського вченого І. Борна (1742-1791), члена масонської ложі. Кантата складається із різних епізодів, таких як аріозо тенора, речитатив 3 акомпанементом та речитатив sессо тенора, та спільним епізодом (соло тенора, хор). А також, «Невелика масонська кантата» (KV 623), для двох тенорів та басу. Цикл твору складається із шести завершених номерів, з яких перший - хоровий, буде в точності повторено в останній частині кантати.

Iз партитурами двох ранніх кантат Л. ван Бетховена можна ознайомитись на сайті «International Music Score Library Project». Обидва твори мають особливу внутрішню будову циклу. Зокрема цикл кантати «На смерть Йосипа II» (для баса та сопрано соло, хору та оркестру) складається із наступних частин: 1) хор, 2) речитатив $\mathrm{B}, 3$ ) арія $\mathrm{B}, 4)$ арія $\mathrm{S}$ з хором (1 розділ соло $\mathrm{S}, 2$ розділ хор), 5) речитатив $S, 6$ ) арія $S, 7$ ) хор.

Кантата « На вступ до царювання Леопольда II» (для солістів сопрано, тенора, баса, мішаного хору та оркестру) складається із: 1) речитативу $\mathrm{S}$ з хором, 2) арії $\mathrm{S}, 3$ ) речитативу $\mathrm{B}, 4)$ речитативу $\mathrm{T}$, 5) терцету, 6) заключного хору.

Організація циклу в обох кантатах Л. ван Бетховена є досить незвичною. Не заглиблюючись у детальний аналіз музичного тексту, можна сказати, що композитор переосмислює цикл, не зважаючи на традиційність оформлення та назви частин. Зокрема, це нове наповнення вже звичних форм, таких як речитатив для соло із хором у супроводі оркестру, або арія 3 хором у супроводі оркестру, переорієнтація тембрів всередині циклу (зміна тембру басу на тембр сопрано у першій кантаті, та почерговий вступ солістів спочатку сопрано, а надалі тенора та басу), що, насамперед, несуть у собі символічне навантаження, а також відображають детальну продуманість задуму композитора.

Відмітимо також особливу роль оркестру, який у Бетховена заповнює простір звучання не тільки арій та хорів, але й речитативів (хоча в кантаті «На вступ до царювання Леопольда ІІ» речитативи тенора і баса, скоріше за все, можна віднести до речитативів secco). Це, в свою чергу, дає можливість прослідкувати на даних творах зустріч та долання композитором двох видів кантат: барокової, із дискретністю структури, типовими видами речитативів, незначною роллю хору у задумі циклу, до кантати нового часу із прагненням наскрізного розвитку, взаємодією між хором, солістами та оркестром. Таким чином, вже у ранніх творах Бетховен підкорює своєму індивідуальному задуму структуру циклу.

Спираючись на детальне вивчення зразків кантат із хором ${ }^{1}$, можна зробити наступні висновки: хор ніколи не виконує функцію персонажу, важливі вузлові моменти розгортання подій ніколи не подаються у партії хору.

Чому це відбувається, які причини додавання хору до складу виконавців сольної кантати?

Найперша - вплив оперного жанру на більшість вокальних та інструментальних жанрів XVIII ст. Видається, що саме так твір збагачується більш урочистим характером виконання та відповідно до естетичних вподобань того часу виглядає більш завершено, оформлено.

Наступна причина - вплив творчості Й. Баха, а саме його духовних концертів, мотетів та пасіонів (які часто називають кантатами) та Г. Генделя (ораторії), де хор грає визначну, а, іноді, й провідну роль, як на композиційному, так і на драматургічному рівнях.

Остання - естетична необхідність у розширенні звукового простору, яка, у свою чергу, вплинула як на формування оркестру за доби класичного стилю, так і на включення хору до складу різних творів (у тому числі й симфоніі).

Жанровий зміст. Окрім різноманітних сюжетів на основі міфів древньої Греції та Риму, 3'являються кантати написані на більш абстрактний сюжет, без залучення відомих міфічних чи історичних персонажів, на тексти німецькою мовою сучасників композиторів-віденців. Зокрема, В. Моцарт писав кантати на тексти Ф. Цигенхагена, Е. Шиканедера та Ф. Петрана, а Л. ван Бетховен - на тексти Й. Гете, А. Вейсенбаха та А. Авердонка. Зауважимо також, що тексти більшості кантат 
В. Моцарта можна віднести до духовних, оскільки твори були приурочені до великого посту, освячення нового масонського храму, або у назві твору прямо чи ж завуальовано згадується про Бога (схоже із назвами духовних концертів та мотетів Й. Баха). Інші тексти кантат можна віднести до урочисто-церемоніальних, що були приурочені на честь винахідника I. Борна та його нового методу амальгамування, коронації короля Бельгії Леопольда II та на смерть короля Німеччини Йосипа II.

Композиційна схема. Бароковий цикл сольної кантати збагачується такими частинами як хор, іноді дует. Окрім того з'являються твори одночастинні із внутрішнім поділом на контрастні розділи, де композиторами (Й. Гайдн, В. Моцарт) знято маркування самостійних частин арії чи речитативу та явним стає прагнення до наскрізного руху. Також зазначимо, що у сольних кантатах віденських класиків спільним для обох видів циклу (із завершеними та означеними номерами і одночастинного) $€$ прагнення до подолання статики та втілення принципів симфонізму таких як контраст, протиставлення та якісні перевтілення тем і тематичних елементів, послідовне та цілеспрямоване втілення музичної драматургії.

Розглянемо одну із найбільш нетипових кантат Моцарта детальніше. Кантата «Ви, пошановувачі Творця безмежного всесвіту» («Die ihr des unermeßlichen Weltalls Schöpfer ehrt») (KV 619) для високого голосу та фортепіано (клавесину), яку можна віднести до виду сольної кантати на текст духовного змісту (cantata spiritual). Твір написаний в останній рік життя композитора. У порівнянні з іншими кантатами, він $є$ найменшим за обсягом композиції (170 тактів).

За кількістю частин, твір нагадує зразки вокальних кантат у супроводі basso continuo Г. Генделя - із характерними частинами: вступ, речитатив та дві арії. Схожа схема будови кантат Генделя та Моцарта краще виявляє відмінні риси у внутрішній будові циклу. Частини циклу в кантатах Генделя були чітко відокремлені одна від одної та оформлювались як замкнений епізод (завдяки єдності гармонічного розвитку, поверненню до основної тональності твору). Як інструментальні, так і вокальні епізоди в кантатах найчастіше були написані у тричастинних формах: $d a$ саро або тричастинна 3 динамізованою репризою. Тому за структурою цикл був подібним до сюїти.

У Моцарта, завдяки насиченій гармонії, частини кантати набувають більшої єдності з явним прагненням до наскрізного руху. Цикл кантати, окрім наскрізного гармонічного розвитку $(C$-dur, $C$ $d u r, a-m o l l, d$-moll, $C$-dur), поєднується і за принципом контрасту: характерів, темпів та метрів розділів:

1 розділ, Andante maestoso, 4/4 - вступ, речитатив;

2 розділ, Andante, $3 / 4$;

3 розділ, Allegro, 4/4;

4 розділ, Andante, 6/8;

5 розділ, Andante, $4 / 4$

6 розділ, Allegro, $4 / 4$.

Із шести розділів кантати, п'ять написані у вигляді невеликих аріозо.

Розділ 2, Andante ( $C$-dur), витриманий у помірному темпі, тридольному метрі, із вокальною партією пісенного типу (рух мелодії по звукам акорду, невеликі за обсягом фрази, хвилеподібна лінія руху мелодії, стрибки на сексту, септиму із плавним заповненням). Простота гармонічного розвитку, (без інтенсивних змін гармоній) та прозора фактура, а також тридольний метр викликають асоціації 3 лендлером².

Розділ 3 складає різкий контраст до попереднього епізоду, що наступає стрімко, лише через восьму паузу. Темп змінюється на Allegro, розмір із тридольного переходить у 4/4. Змінюється також тональний центр на a-moll. Мелодична лінія вокальної партії стає більш різкою, напруженою, схвильованою: початкові ходи на кварту, однорідний ритм, запитально-відповідна структура мелодики 3 елементами декламаційності, широкі стрибки на октаву, елементи риторичних фігур (catabasis, passus duriusculus, exclamatio). Різку зміну характеру підкреслює й гармонія, пульсація якої ущільнюється на відміну від попереднього розділу (зміна гармонії відбувається переважно по півтактах, розвиток відбувається по тональностях: $a$-moll, $d$-moll, $C$-dur, a-moll, $D$-dur, E-dur, $C$-dur, $a$ moll). Партія фортепіано відрізняється частою зміною фактури: спочатку (т. 7885) це - активна мелодія правої руки, що передує вступу вокальної партії. Інтонаційна близькість мелодії в голосі та в партії фортепіано полягає в наслідуванні першої ритмічної фігури (восьма, чверть із крапкою), а також наявності широкого стрибка (у вокальній партії - кварти, т. 80, т. 84; в акомпанементі - октава, т. 78, 82, секста, т. 79, 83). Наступною зміною фактури стає використання ритмічної фігурації 3 другого розділу (наприклад, т. 34) ніби в оберненні (т. 8688), акордові фігурації (т. 9395), та повернення до початкового виду фактури. 
Наступний розділ 4, Andante, 6/8, звучить в $d$-moll. Півтора такти фортепіанного вступу у мелодії віддзеркалюють процес формування першої секстової інтонації у голосі поступовим завоюванням діапазону (т. 107108) від в 3 , ч4, ч ч5. Мелодія вокальної партії аріозного типу. Перша

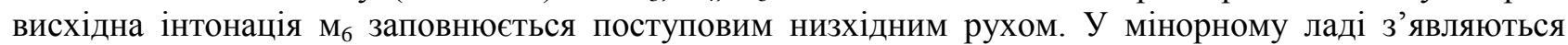
«терпкі» інтонації малих та зменшених інтервалів, $\mathrm{M}_{2}$, 3м (т. 110), а також $3 \mathrm{M}_{3}$ (т. 111). У партії фортепіано, окрім дублювання мелодичної лінії голосу, з'являється виразний підголосок (т. 109111), в якому також ніби застигає низхідна $\mathrm{M}_{2}(d-c i s)$.

Наступний матеріал четвертого розділу (другий період) звучить більш напружено, завдяки активізації фактури, розширенню діапазону нижнього регістру, постійній ритмічній пульсації (восьмими) в партії фортепіано, а наприкінці розділу - низхідній фігурі в октавному подвоєнні, що відносно вокальної партії вступає на другу восьму (т. 125127). Вокальна партія другого періоду, навпаки, відрізняється від попередньої більшою ритмічною стабільністю. Тут переважає формула «четверть - восьма» (т. 122125). Плавність мелодичної лінії порушує зм 4 (т. 122). Певної трансформації зазнає й інтонація висхідної сексти, яка на початку звучала ніжно, а наприкінці розділу змінилась на патетичні заклики (т. 126127). Особливу увагу звертає на себе підголосок у партії фортепіано. Наприклад, у т. 122, поряд із 3м 4 у голосі (по горизонталі), звучить також зм 4 по вертикалі (між двома лініями у партії правої руки, та між підголоском та вокальною партією). Якщо звернути окремо увагу на середній та нижній голоси у партії фортепіано, то тут знаходимо також зменшені

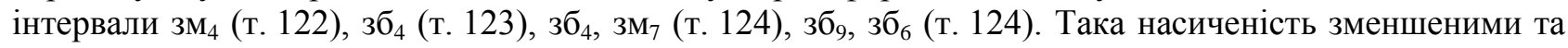
збільшеними інтервалами у прохідному та допоміжному русі додає напруженості загальному звучанню епізоду. Цікаво, що інтервал висхідної сексти змінює свою характеристику із ліричного пісенного на початку розділу, до активно-наративного наприкінці розділу (т. 126127).

5 розділ, Andante a teтро, помітно відрізняється від попереднього, насамперед зміною розміру на 4/4. Змінюється і фактура, тепер - це акордові вертикалі. Гармонія поступово спрощується, інтенсивність зміни акордів на початку розділу складає півтакт, пізніше - від цілого такту до двох тактів. Широкі активні висхідні інтонації у вокальній партії (кварта т. 135136, секста т. 138139) та рух по звуках акордів (т. 141142, т. 144145), а також пульсуючі акорди правої руки створюють враження урочистого промовляння, та нагадують гімнічні жанри.

6 розділ, Allegro, 4/4, виконує функцію коди. Повернення до основної тональності $C$-dur, створює тональну арку із початковими розділами кантати. Протягом всього розділу відбувається кадансування, а прискорення, завдяки зміні темпу та пульсуючої ритмічної одиниці такту (у супроводі в попередньому розділі - восьмі, в останньому - чверті), нагадує типові для Моцарта фінали - швидкі, яскраві, неспинні.

Цікавим прийомом стає наявність речитативно-імпровізаиійних зв'язок. У кантаті «Die ihr des unermeßlichen Weltalls Schöpfer ehrt» це насамперед периий речитатив (т. 1126), що продовжує вступ, а також речитативи № 2 і № 3 між третім та четвертим (т. 105106) та четвертим і п’ятим розділами (т. 128129), що підсилюють відчуття процесуальності, безперервності висловлювання.

Досягнення наскрізного руху у творі забезпечується поступовим зменшенням тривалості епізоду (наприклад розділ $1-26$ тактів, розділ $6-19$ ) та відсутністю повторів у масштабах твору, тобто між розділами, хоча повторність як така зустрічається у двох розділах. Зокрема, у розділі 2 тричастинної форми, останній розділ $\epsilon$ тональною репризою першого, із майже точним повтором чотирьох тактів акомпанементу (т. 63-66) однак іншою мелодією та зміненим кадансом. В наступному розділі 3, написаному також у простій тричастинній формі, останній розділ виконує функцію скороченої динамізованої репризи, де повністю повторені перші три такти із першого розділу (два в акомпанементі, а третій у мелодії, т. 99101).

Висновки. Внаслідок детального вивчення та аналізу численних сольних кантат барокового та класичного стилів виявлено особливі параметри інваріанту, що якісно виокремлюють сольну кантату від інших зразків кантатного жанру. Порівняння двох інваріантів сольних кантат виведемо до окремої таблиці, де у першій колонці перелічені основні параметри жанрового інваріанту, у другій колонці особливості параметрів за доби бароко, і у третій характеристики жанру за доби класичного стилю.

\begin{tabular}{|c|l|l|}
\hline \multicolumn{1}{|c|}{$\begin{array}{c}\text { Параметри жанрового } \\
\text { інваріанту }\end{array}$} & \multicolumn{1}{|c|}{ Бароко } & \multicolumn{2}{|c|}{ Класичний стиль } \\
\hline $\begin{array}{c}\text { соціально-культурна функція } \\
\text { склад виконавців }\end{array}$ & $\begin{array}{l}\text { жанр-постулат } \\
\text { культурної парадигми }\end{array}$ & $\begin{array}{l}\text { репрезентант та учасник } \\
\text { процесу формування нового } \\
\text { жанру- камерної музики }\end{array}$ \\
\hline соліст-вокаліст (або до до & фортепіано, інструментальний \\
\hline
\end{tabular}




\begin{tabular}{|c|c|c|}
\hline & $\begin{array}{l}\text { чотирьох солістів), } \\
\text { інструментальний супровід }\end{array}$ & $\begin{array}{lrr}\text { ансамбль } & \text { збільшений } & \text { до } \\
\text { струнного } & \text { квартету } & \text { iз } \\
\text { додаванням } & \text { духових } \\
\text { iнструментів, або } & \text { навіть } \\
\text { opкестру, іноді хор }\end{array}$ \\
\hline жанровий зміст & $\begin{array}{lrr}\text { наявність } & \text { поетичного } \\
\text { прозового } & \text { світського } \\
\text { духовного) } & \text { (тексту, сюжетність }\end{array}$ & $\begin{array}{l}\text { абстрактний сюжет, без } \\
\text { залучення відомих міфічних } \\
\text { чи історичних персонажів, } \\
\text { використовуються сучасні } \\
\text { тексти німецькою мовою }\end{array}$ \\
\hline композиційна схема & $\begin{array}{l}\text { циклічна композиція (складові } \\
\text { частини: інструментальний } \\
\text { вступ, арія, речитатив, } \\
\text { ритурнелі) }\end{array}$ & $\begin{array}{l}\text { бароковий цикл сольної } \\
\text { кантати збагачується такими } \\
\text { частинами як хор, іноді дует, } \\
\text { одночастинна } \\
\begin{array}{l}\text { композиція із васкрізна } \\
\text { поділом на розділи }\end{array}\end{array}$ \\
\hline
\end{tabular}

Отже, завдяки даній розвідці було виявлено зміну параметрів жанрового інваріанту, притаманних бароковій сольній кантаті, у добу класичного стилю та окреслено причини його перетворень на прикладі кантатних творів віденських класиків в цілому та кантат В. А. Моцарта зокрема.

\section{Примітки}

1 Й. Гайдн кантата «Вибори капельмейстера», В. А. Моцарт кантати «Радість масона», «Невелика масонська кантата», Л. ван Бетховен кантати «На смерть Йосипа II» та «На вступ до царювання Леопольда II».

${ }^{1}$ В. А. Моцарт Кантата «Die ihr des unermeßlichen Weltalls Schöpfer ehrt» (KV 619) для соліста у супроводі фортепіано - $\quad$ http://ks.imslp.net/files/imglnks/usimg/4/48/IMSLP63853-PMLP99640Mozart_Werke_Breitkopf_Serie_07_KV619.pdf

\section{Jimepamypa}

1. Аберт Г. В. А. Моцарт / пер. с нем., коммент. К. К. Саквы. М.: Музыка, 1978. 518 с.

2. Альшванг А. Людвиг ван Бетховен. Очерк жизни и творчества. М.: Музыка, 1977. Изд. 5.445 с.

3. Кирилина Л. Классический стиль в музыке XVIII - начала XIX веков: Самосознание эпохи и музыкальная практика М.: Моск. гос. консерватория, 1996. 192 с.

4. Кремлев Ю. Йозеф Гайдн. М.: Музыка, 1972. 317 с.

5. Тукова I. Функціонування інструментальних жанрових моделей західноєвропейського бароко в українській музиці другої половини XX ст.: автореф. дис. ... канд. мистецтвознавства: 17.00.03. Київ, 2003. 19 с.

6. Alfred Einstein. Mozart / A. Mendel and N. Broder trans. London: Oxford University Press, 1969. 545 p.

7. Bertil van Boer. Historical Dictionary of Music of the Classical Period. Lanham, MD: Rowman \& Littlefield Publishers, Inc., 2012. 664 p.

8. Fortune N., Timms, C., Boyd, M., Krummacher, Fr., Tunley, D. Cantata // The New Grove Dictionary of Music and Musicians / ed. by S. Sadie. 6th ed. London: Macmillan Publishers, 1980. Vol. 3. In. P. 694-718.

9. Kenneth Jaffe. Solo Vocal Works on Jewish Themes: A Bibliography of Jewish Composers. Lanham MD: Rowman \& Littlefield Publishers Inc., 2010. 460 p.

10. Melograni P. Wolfgang Amadeus Mozart: A Biography. Chicago: University of Chicago Press, 2006. $299 \mathrm{p}$.

11. Otto Jahn. Life of Mozart. London: Novello Ever \& Co, 1882. 472 p.

12. Paul F. Rice. Solo Cantata in Eighteenth-Century Britain: A Thematic Catalog. Detroit: Harmonie Park Press, 2002. $463 \mathrm{p}$.

13. Talbot M. Aspects of the Secular Cantata in Late Baroque Italy. London: Taylor \& Francis, 2009. 452 p.

14. Timms C., Fortune N., Boyd M., Krummacher Fr., Tunley D., Goodall J. R., José J. Cantata // Grove Music Online, 2001. [Retrieved from https://doi.org/10.1093/gmo/9781561592630.article.04748 ]

\section{References}

1. Abert, G. (1978). V. A. Mozart (K. Sakwa, Trans.). Moscow: Muzyka. [in Russian]. Russian].

2. Alschwang, A. (1977). Ludwig van Beethoven. Sketch of life and work. Ed. 5. Moscow: Muzyka. [in

3. Kirillina, L. (1996). Classical style in the music of the XVIII - early XIX centuries: Self-consciousness of the epoch and musical practice. Moscow: Mosk. gos. conservatoria. [in Russian].

4. Kremlev, Y. (1972). Joseph Haydn. Moscow: Muzyka. [in Russian]. 
5. Tukova, I. (2003). Functionalization of instrumental genre models of the West European baroque in Ukrainian music of the second half of the twentieth century. Extended abstract of Ph.D. thesis. 17.00.03. Kyiv. [in Ukrainian]

6. Einstein, A. (1969). Mozart (A. Mendel and N. Broder Trans.). London: Oxford University Press.

7. Bertil van Boer. (2012). Historical Dictionary of Music of the Classical Period. Lanham, MD: Rowman \& Littlefield Publishers, Inc.

8. Fortune, N., Timms, C., Boyd, M., Krummacher, Fr., Tunley, D. (1980). Cantata. In: The New Grove Dictionary of Music and Musicians. 6th ed., vol. 3. (ed. by S. Sadie). London: Macmillan Publishers, p. 694-718.

9. Kenneth Jaffe. (2010). Solo Vocal Works on Jewish Themes: A Bibliography of Jewish Composers. Lanham, MD: Rowman \& Littlefield Publishers, Inc.

10. Melograni, P. (2006). Wolfgang Amadeus Mozart: A Biography (Lydia, G. Cochrane Trans.). Chicago: University of Chicago Press.

11. Otto Jahn. (1882). Life of Mozart. (P. D. Townsend, Trans). London: Novello Ever \& Co. Park Press.

12. Paul F. Rice. (2002). Solo Cantata in Eighteenth-Century Britain. (A Thematic Catalog). Detroit: Harmonie $\&$ Francis.

13. Talbot, M. (Eds.). (2009). Aspects of the Secular Cantata in Late Baroque Italy. (1st ed.). London: Taylor

14. Timms, C., Fortune, N., Boyd, M., Krummacher, Fr., Tunley, D., Goodall, J. R., José, J. (2001). Cantata. Grove Music Online. Retrieved from https://doi.org/10.1093/gmo/9781561592630.article.04748

Стаття надійшла до редакиії 19.11.2018 p.

УДК 780.616.433.071.2.(7/8)“19”

\author{
Шадько Максим Олександрович, \\ аспірант, викладач кафедри концертмейстерської \\ майстерності Харківського національного \\ університету мистецтв імені І. П. Котляревського \\ shadkomaksym@gmail.com
}

\title{
НОВИЙ ПІДХІД ДО ВИРАЗОВИХ МОЖЛИВОСТЕЙ ФОРТЕПІАНО У ТВОРЧОСТІ АМЕРИКАНСЬКИХ КОМПОЗИТОРІВ ХХ СТОЛІТТЯ
}

Мета роботи пов'язана 3 розглядом техніко-виразових можливостей фортепіано в творчості американських композиторів-новаторів ХХ століття, висвітленням новітніх способів звуковидобування і зміни тембру та їх ролі у процесі розвитку художньої ідеї. Методологія дослідження полягає у застосуванні історикотеоретичного, структурно-функціонального та порівняльного методів, які дозволяють розкрити своєрідність підходів до фортепіано на сучасному етапі музичного мистецтва та композиційно-драматургічні особливості творів, написаних для перетвореного інструменту. Наукова новизна роботи визначається виявленням процесу еволюційних змін щодо трактування фортепіано американськими композиторами-новаторами минулого століття, що сприяє осмисленню спадкоємних зв'язків між індивідуальними підходами. Висновки. На підгрунті існуючих досліджень та власних аналітичних спостережень доведено, що Г. Кауелл, Дж. Кейдж та Дж. Крам розкрили нові можливості клавішного інструменту, що дозволило кожному з композиторів затвердити новий його підвид: «струнне фортепіано» Г. Кауелла передбачає активне задіяння гри на струнах, «підготовлене фортепіано» Дж. Кейджа - зміну тембру за рахунок немузичних предметів, а «розширене фортепіано» Дж. Крама - гармонійне об’єднання та максимальне збагачення попередніх винаходів в контексті авторської багатогранної художньої концепції. Названі митці поповнили музичну мову оригінальними новаціями та відкрили шлях для подальшого удосконалення піаністичної техніки.

Ключові слова: американські композитори-новатори XX століття, струнне фортепіано Г. Кауелла, підготовлене фортепіано Дж. Кейджа, розширене фортепіано Дж. Крама, нові способи гри на фортепіано.

Шадько Максим Александрович, аспирант, преподаватель кафедры концертмейстерского мастерства Харьковского национального университета искусств имени И. П. Котляревского

Новый подход к выразительным возможностям фортепиано в творчестве американских композиторов XX века

Цель работы связана с рассмотрением технико-выразительных возможностей фортепиано в творчестве американских композиторов-новаторов XX века, освещением новейших способов звукоизвлечения и смены тембра, а также их роли в процессе развития художественной идеи. Методология исследования заключается в применении историко-теоретического, структурно-функционального и сравнительного методов, которые

(C) Шадько М. О., 2019 